\title{
Orexin A Induces GnRH Gene Expression and Secretion from GT1-7 Hypothalamic GnRH Neurons
}

\author{
Ravid Sasson Robert K. Dearth Rachel S. White Patrick E. Chappell \\ Pamela L. Mellon \\ Departments of Reproductive Medicine and Neuroscience and the Center for Reproductive Science and Medicine, \\ University of California at San Diego, La Jolla, Calif., USA
}

\section{Key Words}

Orexin A · Orexin-1 receptor $\cdot$ Gonadotropin-releasing

hormone $\cdot$ GT1-7 cells $\cdot$ Signaling pathways $\cdot$ GnRH neurons

\begin{abstract}
Orexin A, a recently discovered hypothalamic peptide, has been shown to have a stimulatory effect on release of gonadotropin-releasing hormone $(\mathrm{GnRH})$ from rat hypothalamic explants in vitro. However, it is presently unclear whether in vivo this effect is mediated directly at the level of the GnRH neuron, or via multiple afferent neuronal connections. Therefore, in the present study, we investigated the direct action of orexin A on GnRH neurons using the immortalized GnRH-secreting GT1-7 hypothalamic cells. Orexin-1 receptor (OX1R) expression was detected in GT1-7 cells by RT-PCR and Western blot. Results showed that 0.1-1 nM orexin $A$, when administered in culture media for $4 \mathrm{~h}$, can significantly stimulate GnRH mRNA expression in GT1-7 cells $(p<0.05)$. Administration of $1 \mu \mathrm{M}$ OX1R antagonist, SB-334867, completely blocked the observed orexin A responses in these cells, indicating that orexin A stimulation of $\mathrm{GnRH}$ neurons is specifically through OX1R. Moreover, $0.1 \mathrm{nM}$ orexin A stimulated $\mathrm{GnRH}$ release after $30-45 \mathrm{~min}$. To examine possible signal transduction pathways involved in mediating these effects, a MEK inhibitor (UO-126), PKC inhibitor (calphostin C), and PKA inhibitor (H-89), were used,
\end{abstract}

with each blocking orexin A-induced GnRH transcription and release from immortalized cells. Collectively, our results show that orexin A is capable of directly stimulating $\mathrm{GnRH}$ transcription and neuropeptide release from these immortalized hypothalamic neurons, and that the effects of orexin A appear to be mediated via the OX1R, coupled with activation of the PKC-, MAPK- and PKA-signaling pathways. It is suggested that the stimulatory effect of orexin $A$ on $\mathrm{GnRH}$ transcription and release may also occur directly at the level of $\mathrm{GnRH}$ neurons in vivo.

Copyright $\odot 2006$ S. Karger AG, Basel

\section{Introduction}

The 33-amino-acid peptide orexin A, also known as hypocretin $\mathrm{A}$, is a hypothalamic neuropeptide that has been shown to increase food intake and to be involved in the control of energy metabolism [reviewed in 1-3]. A single precursor peptide undergoes proteolytic cleavage to produce both orexin $\mathrm{A}$ and orexin $\mathrm{B}$, a 28 -amino-acid neuropeptide [4]. Previous studies have indicated that, due to structural differences, orexin A has greater resistance to degradation and appears to be more physiologically potent than orexin $B[5,6]$. The actions of orexins are mediated via two $G$ protein-coupled receptors, the orexin1 receptor (OX1R) and orexin-2 receptor (OX2R) [4].

\section{KARGER}

๑ 2006 S. Karger AG, Basel

Fax +4161306 1234

E-Mail karger@karger.ch

www.karger.com
Accessible online at:

www.karger.com/nen
Pamela L. Mellon

Department of Reproductive Medicine, University of California, San Diego

3A14 Leichtag Biomedical Research Building, 9500 Gilman Drive

La Jolla, CA 92093-0674 (USA)

Tel. +1 858534 1312, Fax +1 858534 1438, E-Mail pmellon@ucsd.edu 
Orexin mRNA expression and immunoreactive orexins are mainly localized to the lateral hypothalamus, the posterior hypothalamus, and the perifornical nucleus [4]. Intraventricular administration of orexin A mildly stimulates food intake and energy expenditure. The orexin/ hypocretin system is best known for its role in the maintenance of arousal and waking [reviewed in 1 and 7]. Specifically, orexins are strongly implicated in the pathogenesis of narcolepsy $[8,9]$, a chronic neurological disorder characterized by sudden, brief episodes of sleep that interrupt normal waking [reviewed in 10].

Recent physiological and neuroanatomical studies suggest that orexin A may play a role in the homeostatic regulation of the hypothalamic-pituitary gonadal axis $[5,11-$ 13]. Changes in orexin A release occur concomitant with the estrous cycle in adult female rats, increasing in early proestrus and decreasing in late proestrus [14]. Furthermore, an intracerebroventricular administration of orexin A has been shown to cause recovery of both luteinizing hormone (LH) and prolactin levels that were decreased subsequent to fasting [13] and prepro-orexin mRNA expression is decreased in both $o b / o b$ [15] and $f a / f a$ obese mice [16]. These results suggest that orexin A may communicate changes in metabolic state to the reproductive axis. However, whether orexin A plays a substantial role in dictating reproductive status is poorly understood.

The recent discovery of alterations in gonadotropin secretion by neuropeptides involved in food regulation has provided evidence linking metabolic homeostasis with reproduction. Gonadotropin-releasing hormone $(\mathrm{GnRH})$ secretion is mandatory for reproductive function $[17,18]$ and alterations in GnRH neuronal secretion induced by metabolic neuropeptides result in precocious/delayed puberty $[19,20]$, athletic amenorrhea [21], disrupted menstrual/estrous cycles [22] and infertility [23]. Studies have shown that GnRH cell bodies in the rat are co-localized with the orexin A ligand-specific OX1R [24], and orexinimmunoreactive terminals are found in close proximity with GnRH cells in the preoptic area of sheep [25]. Orexin A dose-dependently inhibited GnRH-stimulated LH release in dispersed pituitaries from proestrous females only [14]. Taken together, these studies suggest an association between orexin A and GnRH signaling; however, whether orexin A directly stimulates GnRH neurons to alter patterns of expression and/or secretion is not known. Notably, orexin A has been shown to induce GnRH release from hypothalamic explants from proestrus rats [14], and intracerebroventricular administration of orexin A antiserum inhibits the preovulatory LH surge in steroid-primed ovariectomized rats [13], implying that orexin A may have the ability to directly regulate $\mathrm{GnRH}$ secretion, subsequently modulating gonadotropin release. Thus, the present study was conducted to determine if orexin A can act directly on GnRH neurons to alter hormonal release and expression in vitro using immortalized $\mathrm{GnRH}$-secreting GT1-7 hypothalamic cells. Because there are a limited number of GnRH neurosecretory cells that are dispersed throughout the preoptic area of the anterior hypothalamus [26], in vivo studies on the direct action of orexin A on GnRH transcription and secretion are difficult. A model of the GnRH neuron was developed through targeted tumorigenesis of the GnRH neuron by SV40 T antigen. Subsequently, a murine immortal cell line of $\mathrm{GnRH}$-secreting hypothalamic neurons, the GT1-7 cells, was established [27]. These cells have many hallmarks of the differentiated GnRH neuron [28-30] including pulsatile secretion of GnRH [31-33]. In this study, we determined that orexin A stimulates GnRH release and mRNA expression from GT1-7 cells. Furthermore, using inhibitors for mitogenactivated protein kinase kinase (MEK), protein kinase $\mathrm{C}$ $(\mathrm{PKC})$, and protein kinase A (PKA), we showed that each resulted in blockade of $\mathrm{GnRH}$ gene expression and release in the presence of orexin A implicating all of these pathways in the regulatory cascade. Finally, we demonstrated that orexin A activates the MAPK pathway by increasing the phosphorylation of extracellular signal-regulated kinase 1/2 (ERK1/2) proteins in GT1-7 cells.

\section{Materials and Methods}

\section{Reagents}

Human orexin A was obtained from Phoenix Pharmaceuticals, Inc. (Belmont, Calif., USA). A selective OX1R antagonist SB334867 was purchased from Tocris (Ellisville, Mo., USA). MEK inhibitor, UO-126, and the PKC inhibitor, calphostin C, were obtained from Calbiochem (San Diego, Calif., USA). PKA inhibitor, $N$-(2-[p-bromocinnamylamino]-ethyl)-5-isoquinolinesulfonamide (H-89), was obtained from Sigma Chemical Co. (St. Louis, Mo., USA).

\section{Animals}

Eight male C57 Black mice (6 weeks of age) were purchased from Harlan Sprague Dawley (Indianapolis, Ind., USA), and housed for 2 weeks in the UCSD animal facility under standard conditions. At 8 weeks of age, mice were sacrificed by decapitation and the hypothalami were collected. Experimental procedures were approved by the Animal Subjects Committee of the University of California, San Diego.

Cell Culture and Experimental Protocols

In experiments measuring GnRH mRNA expression, GT1-7 cells were plated at a density of $0.5 \times 10^{6}$ cells $/ 2-\mathrm{cm}^{2}$ well in DMEM supplemented with $10 \%$ fetal calf serum, 100 units $/ \mathrm{ml}$ 
penicillin, $0.1 \mathrm{mg} / \mathrm{ml}$ streptomycin, and $4.5 \mathrm{mg} / \mathrm{ml}$ glucose. The medium was changed to serum-free DMEM $16 \mathrm{~h}$ before treatment. Cells were treated with either PBS and/or dimethyl sulfoxide $(0.1 \%$ DMSO) as vehicle controls or orexin A $(0.1,1$, or $10 \mathrm{nM}$ diluted in PBS with $0.1 \%$ BSA) for $4 \mathrm{~h}$, after which the cells were lysed to obtain total RNA. This time frame is based on a previous study showing that orexin A does not degrade within $2 \mathrm{~h}$ in culture [34]. GT1-7 cells were pretreated for 30 min with SB-334867 [35], a selective OX1R antagonist, and co-treated during orexin A treatment, to test the specificity of the changes in GnRH secretion induced by orexin ( $1 \mu \mathrm{M}$ of SB-334867 diluted in DMSO vehicle). For signaling experiments, GT1-7 cells were pretreated for $30 \mathrm{~min}$ with the inhibitors to MEK (100 nM UO-126), PKA (10 $\mu \mathrm{M} \mathrm{H}-89)$, or PKC (100 nM calphostin C), and co-treated during orexin A treatment (all inhibitors diluted in DMSO vehicle).

In experiments measuring GnRH release, GT1-7 cells were grown in a monolayer culture and maintained in $10-\mathrm{cm}$ culture plates containing DMEM, supplemented with $10 \%$ fetal calf serum, 100 units $/ \mathrm{ml}$ penicillin, $0.1 \mathrm{mg} / \mathrm{ml}$ streptomycin, and 4.5 $\mathrm{mg} / \mathrm{ml}$ glucose. Cells were incubated under normal conditions $\left(5 \% \mathrm{CO}_{2} / 95 \%\right.$ air atmosphere at $\left.37^{\circ} \mathrm{C}\right)$ for 4 days following plating, or until plates were $80-90 \%$ confluent. Twenty-four hours prior to initial sampling, media was removed, plates were rinsed three times with serum-free media, and replaced with serum-free media. The next day, media was changed, again using serum-free media, then one basal sample $(150 \mu \mathrm{l})$ was collected from every plate to use as baseline GnRH level at time zero. Then cells were challenged by PBS, DMSO (vehicle controls), inhibitors, and/or orexin A $0.1-1 \mathrm{nM}$, as noted in the figures. Media $(150 \mu \mathrm{l})$ was collected at each time point to monitor changes in $\mathrm{GnRH}$ secretion over time or at $45 \mathrm{~min}$ for the dose response. At the end of the experiment, plates of GT1-7 cells were depolarized with $60 \mathrm{mM}$ potassium chloride $(\mathrm{KCl})$ to assess neuronal viability and general secretory function. Increases in secretion due to $\mathrm{KCl}$ were always at least four fold demonstrating viability and secretory function. Collected media samples were stored at $-20^{\circ} \mathrm{C}$ until assayed by radioimmunoassay (RIA) for GnRH content. All inhibitors were used as noted above for mRNA studies.

\section{Reverse Transcriptase - Polymerase Chain Reaction}

Total RNA was isolated from confluent $10-\mathrm{cm}$ plates of cells using Trizol (Invitrogen, Carlsbad, Calif., USA) according to the manufacturer's protocol. One microgram of total RNA isolated was reverse transcribed using SuperScript II enzyme (Invitrogen). Twenty microliters of the reverse transcriptase reactions were amplified using sequence-specific PCR primers for OX1R: forward 5'-GCTTTTTCATTGTCACCTACC-3'; reverse 5'-CAGATAACAGAGTGCAAAAACC-3'. Polymerase chain reaction conditions: $97^{\circ} \mathrm{C}$ for $3 \mathrm{~min}$, then $94^{\circ} \mathrm{C}$ for $30 \mathrm{~s}, 56.5^{\circ} \mathrm{C}$ for $1 \mathrm{~min}, 72^{\circ} \mathrm{C}$ for $1 \mathrm{~min}$ for $35 \mathrm{cycles}$, then $72^{\circ} \mathrm{C}$ for $7 \mathrm{~min}$. To check for possible artifacts generated by amplification of remnants of genomic DNA, control RT-PCR was performed and treated in an identical way but without reverse transcriptase enzyme in the first reaction mixture. Amplified fragments were resolved by $1 \%$ agarose gel electrophoresis and visualized by ethidium bromide staining.

Quantitative Real-Time PCR

RNA was obtained with Trizol reagent (Invitrogen) according to the manufacturer's instructions. Contaminating DNA was removed with DNA-free reagent (Ambion, Inc., Austin, Tex., USA) and $2 \mu \mathrm{g}$ RNA was reverse transcribed using Superscript III Firststrand Synthesis System (Invitrogen). Quantitative real-time PCR was performed in iCycler from Bio-Rad Laboratories, Inc. (Hercules, Calif., USA), using QuantiTect SYBR Green PCR Kit (Qiagen, Valencia, Calif., USA) and the following primers:

\section{GnRH forward: CTACTGCTGACTGTGTGTTTG}

GnRH reverse: CATCTTCTTCTGCCTGGCTTC

GAPDH forward: TGCACCACCAACTGCTTAG

GAPDH reverse: GGATGCAGGGATGATGTTC

under the following conditions: $95^{\circ} \mathrm{C}$ for $15 \mathrm{~min}$, followed by 40 cycles at $95^{\circ} \mathrm{C}$ for $15 \mathrm{~s}, 54^{\circ} \mathrm{C}$ for $30 \mathrm{~s}$, and $72^{\circ} \mathrm{C}$ for $30 \mathrm{~s}$. For $\mathrm{GnRH}$ and GAPDH measurements, the equivalent of $10 \mathrm{ng}$ of starting RNA (as quantified before reverse transcription) was used in each reaction. Each sample was assayed in triplicate, and the experiment was repeated four times. A standard curve with dilutions of $1,000 \mathrm{pg} /$ well, $100 \mathrm{pg} /$ well, $10 \mathrm{pg} /$ well, $1 \mathrm{pg} /$ well, $100 \mathrm{fg} /$ well, and $10 \mathrm{fg} /$ well of a plasmid containing GnRH cDNA and GAPDH cDNA was generated in each experiment with the samples. In each experiment, the amount of GnRH was calculated by comparing threshold cycle obtained for each sample with the standard curve generated in parallel. After each experiment, a melting curve analysis was performed to confirm that a single amplicon was generated in each reaction.

\section{Western Blotting}

Following overnight starvation and treatment with vehicle control or orexin A or SB-334867, GT1-7 cells were rinsed with PBS then lysed with lysis buffer containing $50 \mathrm{mM}$ Hepes ( $\mathrm{pH} 7.2$ ), $150 \mathrm{~mm} \mathrm{NaCl}, 1.5 \mathrm{mM} \mathrm{MgCl}_{2}, 1 \mathrm{~mm}$ EGTA, 1\% Triton X-100, 10\% glycerol, $30 \mathrm{~mm} \mathrm{NaF}, 30 \mathrm{~mm}$ sodium pyrophosphate, $1 \mathrm{~mm}$ orthovanadate, and the protease inhibitors: aprotinin, pepstatin, leupeptin $(10 \mu \mathrm{g} / \mathrm{ml}$ each), and $1 \mathrm{~mm}$ phenylmethylsulfonyl fluoride. Protein concentration was determined with Bradford reagent (Bio-Rad), then $30 \mu \mathrm{g}$ protein per sample was loaded on a sodium dodecyl sulfate-polyacrylamide gel. After proteins had been resolved by electrophoresis and transferred to a polyvinylidene fluoride membrane, they were probed with specific antibodies for phosphorylated-ERK1/2, total-ERK1/2 (Upstate, Lake Placid, N.Y., USA), OX1R and actin (Santa Cruz Biotechnology, Santa Cruz, Calif., USA). The bands were detected with secondary antibodies linked to horseradish peroxidase and enhanced chemiluminescence reagent (Amersham Pharmacia, Piscataway, N.Y., USA) as described by the manufacturer.

\section{Radioimmunoassay}

GnRH primary antibody EL-14 was kindly provided by Martha Bosch, Oline Ronnekleiv, and Martin Kelly (University of Oregon Health Sciences Center, Portland, Oreg., USA). Briefly, $0.1 \mathrm{ml}$ of each sample was incubated for $48 \mathrm{~h}$ with $\mathrm{GnRH}$ antibody at $4^{\circ} \mathrm{C}$, after which time $\sim 10,000 \mathrm{cpm}$ sample of radioiodinated $\mathrm{GnRH}$ (Amersham Pharmacia) was added. Forty-eight hours later, after ethanol precipitation of bound fractions, radioactivity was measured using a gamma counter (Micromedic, Huntsville, Ala., USA). Intra- and interassay variability was 5.3 and $6.4 \%$, respectively.

\section{Statistical Data Analysis}

Fold change in GnRH mRNA level for each treatment group was calculated by averaging replicates and by dividing them by the mean value of GAPDH in the same sample. GnRH mRNA is 

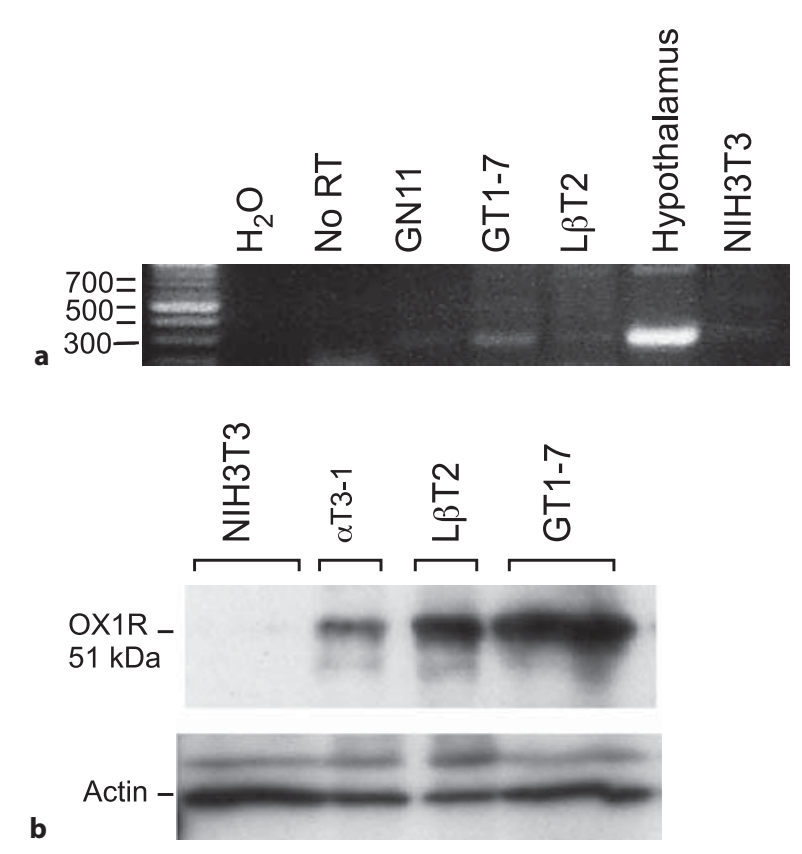

Fig. 1. Expression of OX1R in GT1-7 cells. a Expression of OX1R was analyzed by RT-PCR (35 cycles) in GN11, GT1-7, LßT2, hypothalamus, NIH3T3, and with No RT (no RT served as a negative control). b Western blots were performed using $30 \mu \mathrm{g}$ of whole cell extract of GT1-7, L $\beta$ T2, $\alpha$ T3-1, and NIH3T3. Samples were run on $12 \%$ SDS-PAGE before transfer to nitrocellulose and immunoblotting with antisera that specifically recognized OX1R or actin.

expressed as a ratio from control value for each treatment. GnRH release level for each treatment group was calculated by dividing the value of $\mathrm{GnRH}$ release of each treatment group by the level of $\mathrm{GnRH}$ present at time zero (basal level). All the experiments were repeated at least three times. Results represent the mean \pm SEM of all samples analyzed. '\#' mark statistically significant differences in responses from the control cells determined by one-way ANOVA analysis followed by Turkey's post-hoc multiple range test for individual comparison with $\mathrm{p} \leq 0.05$ or Student's $t$ test as indicated.

\section{Results}

GT1-7 Neurons Express Orexin-1 Receptor $m R N A$ and Protein

Using RT-PCR, we confirmed a previous report [36] showing that OX1R is expressed in GT1-7 cells (fig. 1a), when compared to positive hypothalamic tissue and negative controls (no RT), and not in fibroblast NIH3T3 cells. The mRNA expression level of OX1R was lower in
L $\beta$ T2 cells (immortalized pituitary gonadotropes) and was undetectable in GN11 (an immature GnRH neuronal cell line). In contrast, GT1-7 cells did not express the OX2R (data not shown). Western blot analysis validated our result detecting OX1R protein at approximately 51 $\mathrm{kDa}$ in GT1-7 cells as well as in gonadotrope cell lines, L $\beta$ T2 and $\alpha$ T3-1 (fig. 1b). A relatively higher level of receptor protein was detected in GT1-7 cells compared to the RT-PCR analysis of its mRNA level, probably due to a higher stability or rate of translation of the protein in GT1-7 cells. Since orexin A selectively binds OX1R [4], these and other studies culminate to indicate that orexin $\mathrm{A}$, but not orexin $\mathrm{B}$, may play a larger role governing neuroendocrine functions and thus, orexin $\mathrm{A}$ is the peptide used in the following experiments.

\section{Orexin A Induces Expression of GnRH mRNA via \\ Orexin-1 Receptor in GT1-7 Cells}

GT1-7 cells were treated with increasing concentrations of orexin A (0.001-10 nM) for $4 \mathrm{~h}$. We chose this time frame based on a previous study showing that orexin A does not degrade within $2 \mathrm{~h}$ in culture [37]. Orexin A (0.1-1 nM) caused a significant increase in GnRH mRNA expression in GT1-7 cells after $4 \mathrm{~h}$ of treatment (fig. 2a). A time course showed that the maximal stimulation of gene expression was observed after $4 \mathrm{~h}$ of treatment with orexin A (fig. 2b). Consequently, all subsequent experiments were carried out at the concentration of $0.1 \mathrm{nM}$ of orexin $\mathrm{A}$ for $4 \mathrm{~h}$, which reflects the maximal stimulation.

To investigate whether OX1R mediates the stimulatory effect of orexin A on $\mathrm{GnRH}$, we used the specific OX1R antagonist SB-334867 [35]. GT1-7 cells were pretreated with $1 \mu \mathrm{M} \mathrm{SB}-334867$ for $30 \mathrm{~min}$ before stimulation with $0.1 \mathrm{nM}$ of orexin $\mathrm{A}$ for $4 \mathrm{~h}$. The results show that the two-fold increase in GnRH mRNA expression by orexin A was abolished in the presence of SB-334867 (fig. 2c), indicating that orexin A alters GnRH mRNA expression via specific binding to the OX1R. Recent studies in Chinese hamster ovary cells have shown that OX1R couples to at least three different signaling pathways: (1) $\mathrm{G}_{\mathrm{i} / 0}$ to inhibit cAMP generation; (2) $\mathrm{G}_{\mathrm{s}}$ to stimulate cAMP generation, and (3) PKC (via PLC and $\mathrm{G}_{\mathrm{q}}$ ) to stimulate cAMP generation [38]. To determine which signaling pathway(s) are utilized by orexin A to elicit increases in GnRH mRNA expression in GT1-7 cells, we administered a PKA inhibitor (H-89), a PKC inhibitor (calphostin C) or a MEK inhibitor (UO-126) to GT1-7 cells prior to and during orexin A stimulation (fig. 2c). Pretreatment with each of the inhibitors individually had no significant 


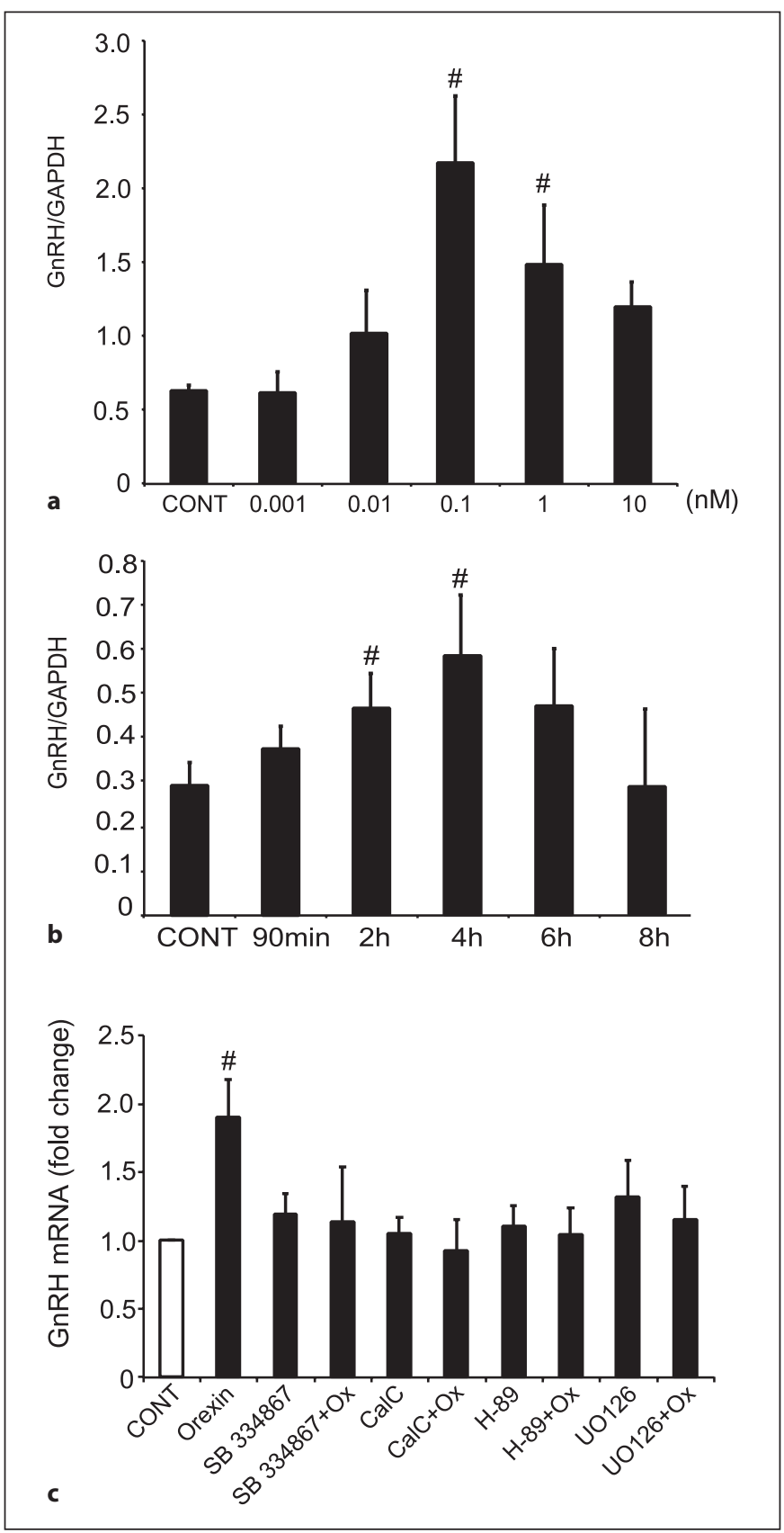

Fig. 2. Orexin A-mediated regulation of $\mathrm{GnRH}$ gene expression in GT1-7 cells involves the PKC, PKA and MAPK pathways. a GT1-7 cells were treated for $4 \mathrm{~h}$ with orexin A (0.001-10 nM) or vehicle alone (CONT). Total RNA was purified and reverse transcribed, and the level of $\mathrm{GnRH}$ expression was assayed by realtime PCR. In each sample, the amount of GnRH mRNA, calculated from the standard curve, was compared with the amount of GAPDH mRNA. Data represent the mean \pm SEM of at least three experiments performed in triplicate. ${ }^{\#}$ Significant difference from CONT as determined by one-way ANOVA and Tukey's post-hoc test, $\mathrm{p}<0.05$. $\mathbf{b}$ GT1-7 cells were treated for the different time points shown with orexin A $(0.1 \mathrm{nM})$ or vehicle alone (CONT). Total RNA was purified and reverse transcribed, and the level of effect on basal GnRH mRNA expression in comparison to control cells. However, administration of each of the cell-signaling inhibitors resulted in a blockade of orexin A-induced GnRH mRNA expression $(\mathrm{p}<0.05)$.

\section{Assessment of the Ability of Orexin A to Directly \\ Induce GnRH Release from GT1-7 Cells}

Orexin A (0.1 nM) significantly stimulated the release of GnRH from GT1-7 cells after 30 and 45 min (fig. 3). This rapid and transient action of orexin A on GT1-7 cells is consistent with that observed in a previous in vitro study using whole hypothalamic explants [14]. To investigate whether OX1R mediates the stimulatory effect of orexin A on GnRH secretion, we used the specific OX1R antagonist SB-334867 [35]. GT1-7 cells were pretreated with $1 \mu \mathrm{M}$ SB-334867 for 30 min before stimulation with $0.1 \mathrm{nM}$ of orexin A for $45 \mathrm{~min}$. Our results show that the four-fold increase in $\mathrm{GnRH}$ release by orexin A was abolished in the presence of SB-334867 (fig. 3c), indicating that orexin A alters $\mathrm{GnRH}$ secretion via specific binding to the OX1R.

\section{Effects of PKA, PKC, and MAPK Inhibitors on Orexin} A-Induced GnRH Release

We were also interested in investigating the signaling pathways involved in the orexin A-mediated stimulation of GnRH release in GT1-7 cells. To determine which signaling pathway(s) are involved in orexin A-mediated increases in GnRH secretion from GT1-7 cells, we administered a PKA inhibitor (H-89), a PKC inhibitor (calphostin C), or a MEK inhibitor (UO-126) to GT1-7 cells prior to and during orexin A stimulation (fig. 4a). Pretreatment with each of the inhibitors individually had no significant effect on GnRH release in comparison to control

GnRH expression was assayed by real-time PCR. In each sample, the amount of GnRH, calculated from the standard curve, was compared with the amount of GAPDH. Data represent the mean \pm SEM of at least three experiments performed in triplicate. \# Significant difference from CONT as determined by one-way ANOVA and Tukey's post-hoc test, p $<0.05$. c GT1-7 cells were pretreated $(30 \mathrm{~min})$ and co-treated with a specific antagonist to OX1-R (1 $\mu \mathrm{M}$ of SB-334867), PKA inhibitor (10 $\mu \mathrm{M} \mathrm{H-89),} \mathrm{PKC}$ inhibitor (100 nM calphostin C), MEK inhibitor (100 nM UO-126), or with vehicle alone (CONT) prior to and during treatment with orexin A (Ox; $0.1 \mathrm{~nm})$ or vehicle alone for $4 \mathrm{~h}$. " Significant difference from CONT as determined by one-way ANOVA and Tukey's post-hoc test, $\mathrm{p}<0.05$. 


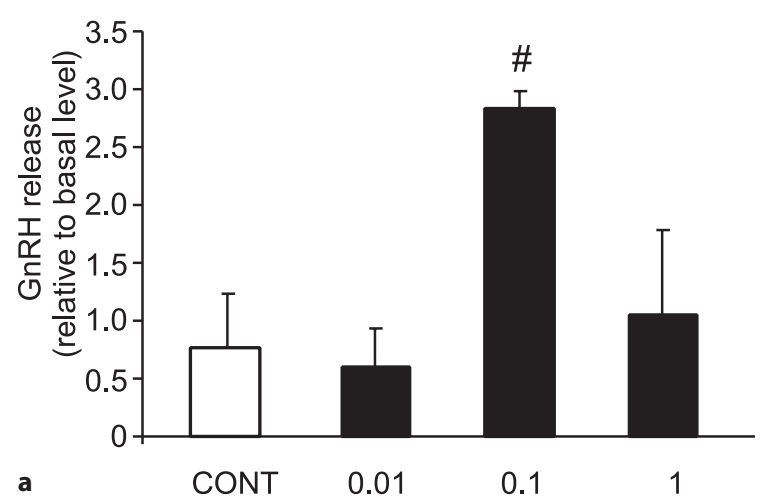

cells. However, administration of each of the cell-signaling inhibitors resulted in a blockade of orexin A-induced GnRH release ( $0.1 \mathrm{nM} ; \mathrm{p}<0.05)$, exhibiting secretory levels comparable to vehicle- and pre-treated controls. Supporting this, orexin A $(0.1 \mathrm{nM})$ transiently increases ERK1/2 phosphorylation within 4 min in GT1-7 cells, as illustrated by the immunoblot in figure $4 \mathrm{~b}$. Moreover, in the presence of SB-334867, there was a visible reduction in ERK1/2 phosphorylation induced by treatment with orexin A for 8 min (fig. 4 b).

\section{Discussion}

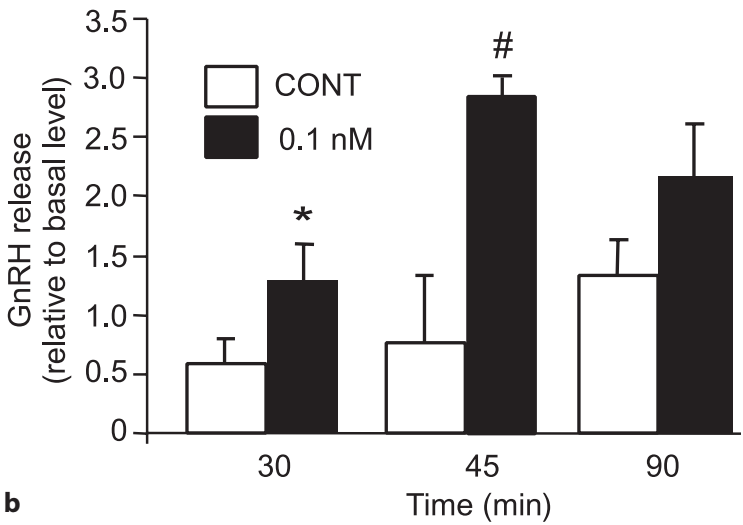

The mammalian reproductive system is highly sensitive to changes in metabolic state, manifested by alterations in nutrient availability. Orexin A has been proposed to serve as a metabolic gate to the reproductive system to indicate that sufficient nutritional stores are available for reproduction. Orexin neurons exert at least part of this control through the facilitation of hypothalamic $\mathrm{GnRH}$ release, since it was shown that orexin A increased GnRH secretion from hypothalamic explants of intact males and females in vitro [14]. Despite this finding, the mechanism of action of orexin A on GnRH neuronal function was unclear. In this study, we have confirmed that OX1R mRNA is expressed in GT1-7 cells, as was shown previously by Yang et al. [36]. Moreover, we have shown the expression of OX1R at the protein level by Western blotting. In addition, OX1R expression was also detected at high level in the pituitary gonadotrope cell line, L $\beta$ T2. This observation is consistent with studies in rats, human and sheep [39-41] supporting the potential role of orexin A in the regulation of reproductive neuroendocrine processes at the pituitary level. Furthermore, we demonstrated that orexin A likely stimulates GnRH mRNA expres-

Fig. 3. Orexin A increases GnRH secretion from GT1-7 via specific binding to OX1-R. a GT1-7 cells were treated for $45 \mathrm{~min}$ with orexin A (0.01-1 nM) or vehicle alone (CONT). Cell culture medium was then collected and assayed for GnRH release by RIA. $\mathrm{GnRH}$ release was calculated by normalizing to the level of $\mathrm{GnRH}$ in the plates at time zero and is show as the actual increase relative to the level at time zero. Results shown are mean \pm SE $(n=$ three independent experiments each in triplicate; \# Student's t test was used, p < 0.05). b GT1-7 cells were treated for different time points shown with orexin A ( $0.1 \mathrm{nM})$ or vehicle alone (CONT). Cell cul-

ture medium was then collected and assayed for $\mathrm{GnRH}$ release by RIA. Results shown are mean $\pm \mathrm{SE}(\mathrm{n}=$ three independent experiments each in triplicate; ${ }^{\#}$ Student's t test was used, $\mathrm{p}<0.05$ ). c GT1-7 cells were pretreated (30 min) with $1 \mu \mathrm{M}$ of SB-334867 or with vehicle alone prior to and during treatment with orexin $\mathrm{A}$ $(0.1 \mathrm{nM})$ or vehicle alone for $45 \mathrm{~min}$. Cell culture medium was then collected and assayed for $\mathrm{GnRH}$ release by RIA. Results shown are mean \pm SE $(n=$ three independent experiments each in triplicate; " one-way ANOVA followed by the Tukey-Kramer HSD post-hoc test was used, $\mathrm{p}<0.05$ ). 
Fig. 4. Orexin A-mediated GnRH release from GT1-7 cells involves the PKC, PKA and MAPK pathways. a GT1-7 cells were pretreated (30 min) with the PKA inhibitor $(10 \mu \mathrm{M} \mathrm{H}-89)$, PKC inhibitor (100 nM calphostin C), MEK inhibitor (100 nM UO-126), or with vehicle alone (CONT) prior to and during treatment with orexin A $(0.1 \mathrm{nM})$ or vehicle alone for $45 \mathrm{~min}$. Cell culture medium was then collected and assayed for GnRH release by RIA. Results shown are mean $\pm \mathrm{SE}(\mathrm{n}=$ three independent experiments each in triplicate; ${ }^{\#}$ oneway ANOVA followed by the Tukey-Kramer HSD post-hoc test was used, $\mathrm{p}<0.05$ ). b GT1-7 neurons were serum-starved for $24 \mathrm{~h}$ prior to treatment with $0.1 \mathrm{nM}$ orexin A for different time points or were pretreated $(30 \mathrm{~min})$ and co-treated with $1 \mu \mathrm{M}$ of SB-334867 prior to and during treatment with $0.1 \mathrm{nM}$ of orexin A or vehicle for $8 \mathrm{~min}$. Cell lysates were resolved on $12 \%$ SDS-PAGE before transfer to nitrocellulose and immunoblotting with antisera that specifically recognized total ERK1/2 or phospho-ERK1/2. A representative Western blot is shown ( $\mathrm{n}=3$ independent experiments).

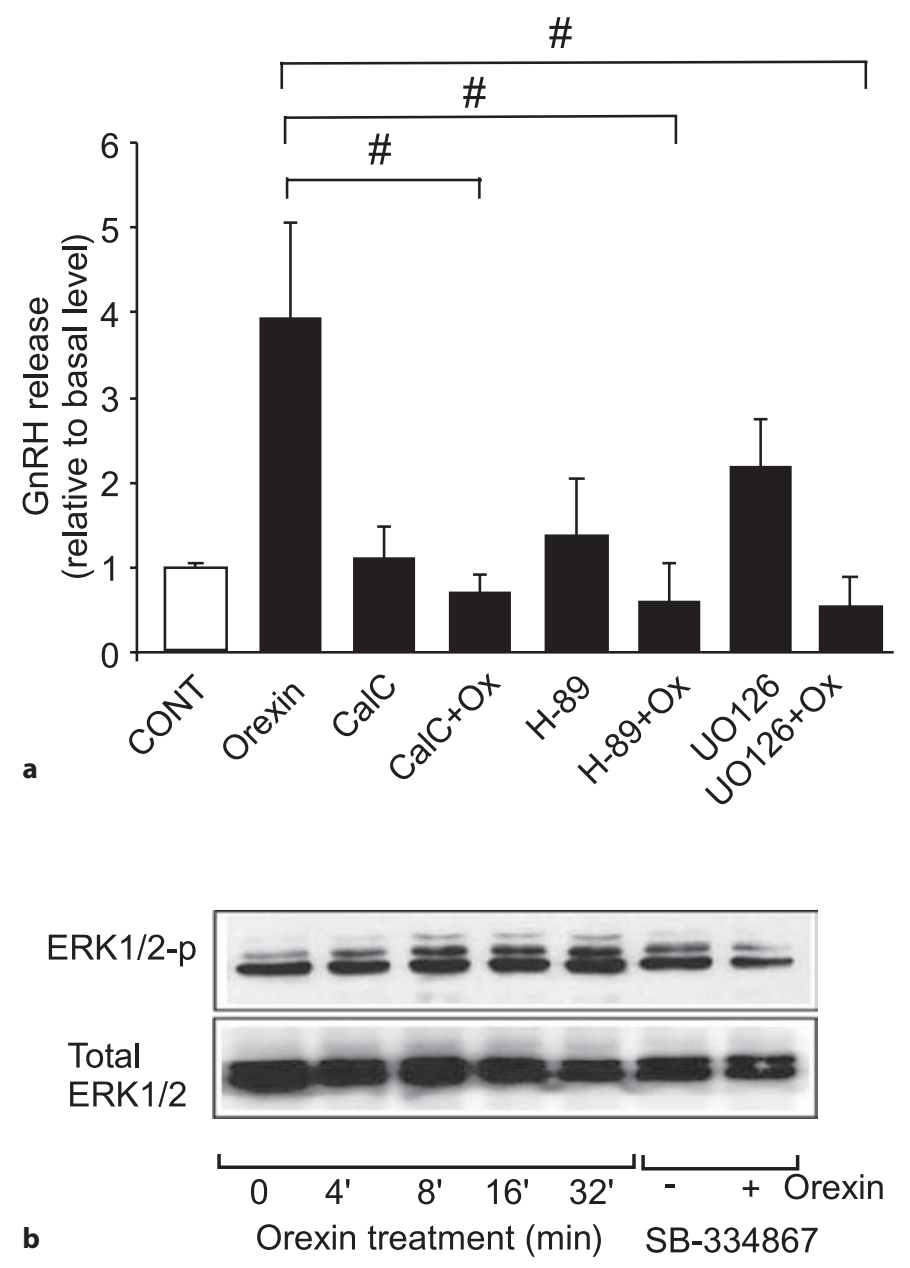

sion and release in vivo by a direct action, using immortalized, GnRH-producing GT1-7 cells in vitro. This action appears to be primarily mediated by the OX1R subtype. No previous studies have been published on the responses of GnRH gene expression to orexin A in GT1-7 cells. In addition, orexin $\mathrm{A}$ increased $\mathrm{GnRH}$ mRNA expression. It is possible that orexin A affects gene transcription either directly and/or indirectly, and/or may have an effect on GnRH mRNA stability. Further studies are required to determine at what level orexin $A$ acts to regulate GnRH mRNA levels. In a previous report, no effect of orexin A on GnRH release in GT1-7 cells was reported [36]. However, in the current study, a lower concentration of orexin A was used ( $0.1 \mathrm{nM}$ instead of $1 \mathrm{nM}$ as the lowest dose), under different cell culture conditions. The most effective dose of orexin A that showed regulation of $\mathrm{GnRH}$ expression and release is $0.1 \mathrm{nM}$. The physiological concentration of orexin A in hypothalamic tissue has been shown to be dependent on the days of the estrous cycle in female rats [42]. The hypothalamic orexin A concentration was $0.25 \mathrm{nM}$ on the days of estrus and $0.7 \mathrm{nM}$ on the days of proestrus [42]. Therefore, the orexin A concentration used in our study is very close to the range of physiological concentrations of orexin $\mathrm{A}$ in the brain. This may explain the lack of response to orexin $A$ in the Yang et al. [36] study, since they used a dose range of 
1-500 $\mathrm{nM}$. In addition, since orexin A is not only involved in signaling metabolic state, but also wakefulness and arousal $[43,44]$, a requirement for a low dose would prevent $\mathrm{GnRH}$ stimulation from occurring too indiscriminately. Another possible explanation for the lack of response to higher concentrations of orexin $\mathrm{A}$ is that OX1R may exist as a functional dimer in GT1-7 cells. It was demonstrated that OX1-R can heterodimerize with the cannabinoid CB1 receptor, which results in alterations of receptor localization and function [45]. However, whether OX1Rs may exist and potentially function as homodimers remains to be examined. To our knowledge this is not the first demonstration of an atypical dose effect for a receptor. It is well described for both growth hormone and prolactin that activation of their receptors involves ligand-induced sequential receptor homodimerization. In an excess of ligand, they are unable to induce receptor dimerization due to the hormone's ability to block the receptor in the inactive H1:R1 stoichiometry (one hormone, one receptor) $[46,47]$.

Corroborating our findings on $\mathrm{GnRH}$ stimulation in response to orexin $\mathrm{A}$ are numerous physiological and morphological studies supporting the concept of direct orexin A regulation of $\mathrm{GnRH}$ release in vivo. $\mathrm{GnRH}$ cell bodies in the rat are co-localized with the orexin A ligand-specific OX1R [24], and orexin-immunoreactive terminals are found in close proximity with $\mathrm{GnRH}$ cells in the preoptic area of sheep [25]. Direct actions of orexin A on GnRH neurons are also suggested by the fact that orexin A can stimulate GnRH release from hypothalamic explants of intact males and females in vitro, also after $45 \mathrm{~min}$ [14], as we observed in our study. Moreover, intracerebroventricular administration of orexin A antiserum was shown to inhibit the preovulatory LH surge, implying that orexin A may have the ability to directly regulate GnRH secretion, thus modulating gonadotropin release [13]. Additionally, it was shown very recently, by measuring the changes of the membrane potential of GnRH neurons, that orexin A, like NPY, had a direct effect on the GnRH neuron [M.S. Smith et al.: Abstract, Endocrine Society Annual Meeting, 2006]. Our findings of regulation of both GnRH mRNA expression and secretion by orexin A in GT1-7 cells support the hypothesis that the GnRH neurons of the hypothalamus are a direct target of orexin A.

PKA and PKC second messengers have been implicated in the regulation of GnRH gene expression in GT1-7 cells. Activation of PKA activity has been reported to have no effect [48] as well as inhibit [49] GnRH gene expression in GT1-7 cells. PKC signaling has been shown to downregulate GnRH gene expression [48, 50, 51]. In the present study, treatment with PKA or PKC inhibitors alone did not alter basal GnRH gene expression. These results support previous studies that showed that activation of adenylyl cyclase by forskolin, to raise cAMP levels, or treatment with the PKC inhibitor, bisindolylmaleimide, also had no effect on the steady-state level of GnRH mRNA levels over 48 and 24 h, respectively [48, 52]. In the presence of PKA or PKC inhibitors, there was a decrease in the orexin A-mediated increase of $\mathrm{GnRH}$ mRNA levels, suggesting that the PKA and PKC pathways may be involved in the orexin A-mediated induction of GnRH gene expression. OX1R has been shown to be able to activate $G_{i}, G_{s}$ and $G_{q / 11}$ proteins in Chinese hamster ovary cells [38]. Since both $\mathrm{Gi}$ and $\mathrm{G}_{\mathrm{q} / 11}$ proteins have been shown to activate the MAPK pathway [53-55], we decided to investigate the possible involvement of this signaling pathway in orexin A-mediated GnRH gene expression as well. Treatment with a MEK inhibitor did not alter basal GnRH mRNA expression, as has been shown in earlier study [52]. In the presence of the MEK inhibitor, we showed that the response to orexin A is decreased, implying that the MAPK pathway is involved in orexin A-mediated increase in GnRH gene expression. Further studies will be aimed at identifying the downstream elements of these pathways involved in the induction of $\mathrm{GnRH}$ gene expression mediated by orexin A.

The signaling mechanisms involved in the regulation of GnRH secretion in GT1-7 cells are yet to be completely understood. Previous studies have shown the role of the PKA-signaling pathway in the stimulation of GnRH secretion, where dopamine and norepinephrine have been shown to increase intracellular cAMP levels and stimulate pulsatile GnRH secretion in GT1-7 cells [56]. Stimulation of PKC activity has also been shown to enhance GnRH secretion from GT1-7 cells [57]. Our results indicate that pharmacological inhibition of the PKA, PKC, or the ERK1/2 pathway resulted in inhibition of $\mathrm{GnRH}$ release induced by orexin A. These results suggest that all of these pathways are required for orexin A-mediated increase of GnRH secretion. These results support previous studies that showed that each of the PKA-, PKCand MAPK-signaling pathways are involved in altering GnRH secretion [52]. In particular, Roy and Belsham [52] have shown that all three of these pathways are necessary for melatonin-mediated suppression of $\mathrm{GnRH}$ secretion. A possible explanation for the observation of total blockade of the effects of orexin A by the inhibitors of the three signaling pathways is the evidence that the stimulatory effect of OX1R on adenylyl cyclase requires an interplay 
of PKC and Gs proteins in Chinese hamster ovary [38]. In these cells, in the presence of Gs activity, the response of cAMP elevation by orexin A was fully dependent on PKC $\delta$. Therefore, this could explain the cross-talk between the cellular signals that PKA and PKC triggers upon orexin receptor activation that are not fully independent signals. In our study on $\mathrm{GnRH}$ mRNAs using a pharmacological approach, we concluded that PKA, PKC and MAPK pathways are involved in the orexin A response, but since the orexin stimulation is modest in GT1-7 cells, it is difficult to judge the degree of the involvement of these pathways individually. It is of interest that each of these kinase inhibitors alone evoked a slight increase in GnRH secretion and expression that was not statistically significant, suggesting that, in the absence of a stimulatory factor such as orexin A, these signaling pathways are required for a basal repression of $\mathrm{GnRH}$ secretion. These results agree with another recent study that demonstrated that pharmacological inhibition of the PKA, PKC, or ERK1/2 pathways in GT1-7 neurons resulted in an increase in the basal secretion of GnRH [58].

We have also found that orexin A stimulation increases phosphorylation of ERK1/2, an action specifically me- diated by OX1R. While little is currently understood about the mechanisms of regulation by the OX1R in GT17 cells, our results on phosphorylation of ERK1 and ERK2 are compatible with a recent study that demonstrated activation of ERK1/2 by orexin A in HEK-293T cells and in Chinese hamster ovary cells transfected with OX1R [59, 60].

In summary, these in vitro studies show that orexin $\mathrm{A}$ stimulates GnRH gene expression and release from GT17 cells, suggesting that this stimulatory effect of orexin A may also occur directly at the level of $\mathrm{GnRH}$ neurons in vivo. Future work will examine the effect of orexin A on $\mathrm{GnRH}$ neurons in situ to prove this hypothesis.

\section{Acknowledgments}

We thank Martha Bosch, Oline Ronnekleiv, and Martin Kelly for kindly providing the $\mathrm{GnRH}$ antibody. This work was supported by NIH/NIDDK R01 DK044838 to P.L.M. It was also supported by NIH/NICHD through a cooperative agreement (U54 HD012303) as part of the Specialized Cooperative Centers Program in Reproduction Research to P.L.M. R.K.D. and P.E.C. were supported in part by NIH T32 HD007203. P.E.C. was also supported by F32 DK10100 and K01 DK64919.

\section{References}

1 Siegel JM: Hypocretin (orexin): role in normal behavior and neuropathology. Annu Rev Psychol 2004;55:125-148.

- Zheng $\mathrm{H}$, Patterson LM, Berthoud HR: Orexin-A projections to the caudal medulla and orexin-induced c-Fos expression, food intake, and autonomic function. J Comp Neurol 2005;485:127-142.

>3 Lubkin M, Stricker-Krongrad A: Independent feeding and metabolic actions of orexins in mice. Biochem Biophys Res Commun 1998;253:241-245.

-4 Sakurai T, Amemiya A, Ishii M, Matsuzaki I, Chemelli RM, Tanaka H, Williams SC, Richardson JA, Kozlowski GP, Wilson S, Arch JR, Buckingham RE, Haynes AC, Carr SA, Annan RS, McNulty DE, Liu WS, Terrett JA, Elshourbagy NA, Bergsma DJ, Yanagisawa M: Orexins and orexin receptors: a family of hypothalamic neuropeptides and G proteincoupled receptors that regulate feeding behavior. Cell 1998;92:573-585.

$\checkmark 5 \mathrm{Pu}$ S, Jain MR, Kalra PS, Kalra SP: Orexins, a novel family of hypothalamic neuropeptides, modulate pituitary luteinizing hormone secretion in an ovarian steroid-dependent manner. Regul Pept 1998;78:133-136.
6 Edwards CM, Abusnana S, Sunter D, Murphy KG, Ghatei MA, Bloom SR: The effect of the orexins on food intake: comparison with neuropeptide $Y$, melanin-concentrating hormone and galanin. J Endocrinol 1999;160: R7-R12.

7 Sakurai T: Roles of orexins and orexin receptors in central regulation of feeding behavior and energy homeostasis. CNS Neurol Disord Drug Targets 2006;5:313-325.

$\checkmark 8$ Hagan JJ, Leslie RA, Patel S, Evans ML, Wattam TA, Holmes S, Benham CD, Taylor SG, Routledge C, Hemmati P, Munton RP, Ashmeade TE, Shah AS, Hatcher JP, Hatcher PD, Jones DN, Smith MI, Piper DC, Hunter AJ, Porter RA, Upton N: Orexin A activates locus coeruleus cell firing and increases arousal in the rat. Proc Natl Acad Sci USA 1999; 96:10911-10916.

-9 Willie JT, Chemelli RM, Sinton CM, Yanagisawa M: To eat or to sleep? Orexin in the regulation of feeding and wakefulness. Annu Rev Neurosci 2001;24:429-458.

10 Saper CB, Scammell TE, Lu J: Hypothalamic regulation of sleep and circadian rhythms. Nature 2005;437:1257-1263.
11 Tamura T, Irahara M, Tezuka M, Kiyokawa $\mathrm{M}$, Aono T: Orexins, orexigenic hypothalamic neuropeptides, suppress the pulsatile secretion of luteinizing hormone in ovariectomized female rats. Biochem Biophys Res Commun 1999;264:759-762.

12 Furuta M, Funabashi T, Kimura F: Suppressive action of orexin A on pulsatile luteinizing hormone secretion is potentiated by a low dose of estrogen in ovariectomized rats. Neuroendocrinology 2002;75:151-157.

13 Kohsaka A, Watanobe H, Kakizaki Y, Suda T, Schioth HB: A significant participation of orexin-A, a potent orexigenic peptide, in the preovulatory luteinizing hormone and prolactin surges in the rat. Brain Res 2001;898: 166-170.

14 Russell SH, Small CJ, Kennedy AR, Stanley SA, Seth A, Murphy KG, Taheri S, Ghatei MA, Bloom SR: Orexin A interactions in the hypothalamo-pituitary-gonadal axis. Endocrinology 2001;142:5294-5302.

15 Yamamoto Y, Ueta Y, Date Y, Nakazato M, Hara Y, Serino R, Nomura M, Shibuya I, Matsukura S, Yamashita H: Down-regulation of the prepro-orexin gene expression in genetically obese mice. Brain Res Mol Brain Res 1999;65:14-22. 
- 16 Yamamoto Y, Ueta Y, Yamashita H, Asayama $\mathrm{K}$, Shirahata A: Expressions of the preproorexin and orexin type 2 receptor genes in obese rat. Peptides 2002;23:1689-1696.

- 17 Karsch FJ, Bowen JM, Caraty A, Evans NP, Moenter SM: Gonadotropin-releasing hormone requirements for ovulation. Biol Reprod 1997;56:303-309.

-18 Levine JE, Bauer-Dantoin AC, Besecke LM, Conaghan LA, Legan SJ, Meredith JM, Strobl FJ, Urban JH, Kirsten VM, Wolfe AM: Neuroendocrine regulation of the luteinizing hormone-releasing hormone pulse generator in the rat. Recent Prog Horm Res 1991; 47:97-151.

19 Minami S, Sarkar DK: Central administration of neuropeptide $\mathrm{Y}$ induces precocious puberty in female rats. Neuroendocrinology 1992;56:930-934.

-20 Sutton SW, Mitsugi N, Plotsky PM, Sarkar DK: Neuropeptide Y: a possible role in the initiation of puberty. Endocrinology 1988; 123:2152-2154.

21 Loucks AB, Horvath SM: Athletic amenorrhea: a review. Med Sci Sports Exer 1985;17: 56.

-22 Estrada KM, Pompolo S, Morris MJ, Tilbrook AJ, Clarke IJ: Neuropeptide Y (NPY) delays the oestrogen-induced luteinizing hormone $(\mathrm{LH})$ surge in the ovariectomized ewe: further evidence that NPY has a predominant negative effect on $\mathrm{LH}$ secretion in the ewe. J Neuroendocrinol 2003;15:10111020.

23 Smith GD, Jackson LM, Foster DL: Leptin regulation of reproductive function and fertility. Theriogenology 2002;57:73-86.

-24 Campbell RE, Grove KL, Smith MS: Gonadotropin-releasing hormone neurons coexpress orexin-1 receptor immunoreactivity and receive direct contacts by orexin fibers. Endocrinology 2003;144:1542-1548.

-25 Iqbal J, Pompolo S, Sakurai T, Clarke IJ: Evidence that orexin-containing neurones provide direct input to gonadotropin-releasing hormone neurones in the ovine hypothalamus. J Neuroendocrinol 2001;13:10331041.

-26 Schwanzel-Fukuda M, Jorgenson KL, Bergen HT, Weesner GD, Pfaff DW: Biology of normal luteinizing hormone-releasing hormone neurons during and after their migration from olfactory placode. Endocr Rev 1992;13:623-634.

27 Mellon PL, Windle JJ, Goldsmith P, Pedula C, Roberts J, Weiner RI: Immortalization of hypothalamic GnRH neurons by genetically targeted tumorigenesis. Neuron 1990;5:110.

28 Wetsel WC, Mellon PL, Weiner RI, NegroVilar A: Metabolism of pro-LHRH in immortalized hypothalamic neurons. Endocrinology 1991;129:1584-1595.
29 Whyte DB, Lawson MA, Belsham DD, Eraly SA, Bond CT, Adelman JP, Mellon PL: A neuron-specific enhancer targets expression of the gonadotropin-releasing hormone gene to hypothalamic neurosecretory neurons. Mol Endocrinol 1995;9:467-477.

30 Liposits Z, Merchenthaler I, Wetsel WC Reid JJ, Mellon PL, Weiner RI, Negro-Vilar A: Morphological characterization of immortalized hypothalamic neurons synthesizing luteinizing hormone-releasing hormone. Endocrinology 1991;129:1575-1583.

31 Wetsel WC, Valença MM, Merchenthaler I, Liposits Z, López FJ, Weiner RI, Mellon PL, Negro-Vilar A: Intrinsic pulsatile secretory activity of immortalized LHRH secreting neurons. Proc Natl Acad Sci USA 1992;89. 4149-4153.

32 Weiner RI, Martinez de la Escalera G: Pulsatile release of gonadotrophin-releasing hormone $(\mathrm{GnRH})$ is an intrinsic property of GT1 GnRH neuronal cell lines. Hum Reprod 1993;2:13-17.

33 Chappell PE, White RS, Mellon PL: Circadian gene expression regulates pulsatile gonadotropin-releasing hormone $(\mathrm{GnRH})$ secretory patterns in the hypothalamic GnRH-secreting GT1-7 cell line. J Neurosci 2003;23:11202-11213

34 Yoshida H, Beltran-Parrazal L, Butler P Conti M, Charles AC, Weiner RI: Lowering cyclic adenosine-3', 5' $^{\prime}$-monophosphate (cAMP) levels by expression of a cAMP-specific phosphodiesterase decreases intrinsic pulsatile gonadotropin-releasing hormone secretion from GT1 cells. Mol Endocrinol 2003;17:1982-1990.

35 Smart D, Sabido-David C, Brough SJ, Jewitt F, Johns A, Porter RA, Jerman JC: SB334867-A: the first selective orexin-1 receptor antagonist. Br J Pharmacol 2001;132: 1179-1182.

36 Yang Y, Zhou LB, Liu SQ, Tang JF, Li FY, Li RY, Song HD, Chen MD: Expression of feeding-related peptide receptors $\mathrm{mRNA}$ in GT17 cell line and roles of leptin and orexins in control of GnRH secretion. Acta Pharmacol Sin 2005;26:976-981.

37 Yoshida Y, Fujiki N, Maki RA, Schwarz D, Nishino S: Differential kinetics of hypocretins in the cerebrospinal fluid after intracerebroventricular administration in rats Neurosci Lett 2003;346:182-186.

$>38$ Holmqvist T, Johansson L, Ostman M, Ammoun S, Akerman KE, Kukkonen JP: OX1 orexin receptors couple to adenylyl cyclase regulation via multiple mechanisms. J Biol Chem 2005;280:6570-6579.

-39 Johren O, Neidert SJ, Kummer M, Dendorfer A, Dominiak P: Prepro-orexin and orexin receptor mRNAs are differentially expressed in peripheral tissues of male and female rats. Endocrinology 2001;142:3324-3331.
40 Blanco M, Lopez M, Garcia-Caballero T, Gallego R, Vazquez-Boquete A, Morel G, Senaris R, Casanueva F, Dieguez C, Beiras A: Cellular localization of orexin receptors in human pituitary. J Clin Endocrinol Metab 2001;86:1616-1619.

41 Zhang S, Blache D, Vercoe PE, Adam CL, Blackberry MA, Findlay PA, Eidne KA, Martin GB: Expression of orexin receptors in the brain and peripheral tissues of the male sheep. Regul Pept 2005;124:81-87.

42 Porkka-Heiskanen T, Kalinchuk A, Alanko L, Huhtaniemi I, Stenberg D: Orexin A and $B$ levels in the hypothalamus of female rats: the effects of the estrous cycle and age. Eur J Endocrinol 2004;150:737-742.

43 Burdakov D, Alexopoulos H: Metabolic state signalling through central hypocretin/orexin neurons. J Cell Mol Med 2005;9:795-803.

44 Baumann CR, Bassetti CL: Hypocretins (orexins) and sleep-wake disorders. Lancet Neurol 2005;4:673-682.

45 Ellis J, Pediani JD, Canals M, Milasta S, Milligan G: Orexin-1 receptor-cannabinoid CB1 receptor hetero-dimerization results in both ligand-dependent and -independent co-ordinated alterations of receptor localization and function. J Biol Chem 2006;281:3881238824.

46 Fuh G, Cunningham BC, Fukunaga R, Nagata S, Goeddel DV, Wells JA: Rational design of potent antagonists to the human growth hormone receptor. Science 1992;256: 1677-1680.

47 Goffin V, Kinet S, Ferrag F, Binart N, Martial JA, Kelly PA: Antagonistic properties of human prolactin analogs that show paradoxical agonistic activity in the $\mathrm{Nb} 2$ bioassay. J Biol Chem 1996;271:16573-16579.

48 Wetsel WC, Eraly SA, Whyte DB, Mellon PL: Regulation of gonadotropin-releasing hormone by protein kinases $\mathrm{A}$ and $\mathrm{C}$ in immortalized hypothalamic neurons. Endocrinology 1993;132:2360-2370.

49 Lei ZM, Rao CV: Signaling and transacting factors in the transcriptional inhibition of gonadotropin-releasing hormone gene by human chorionic gonadotropin in immortalized hypothalamic GT1-7 neurons. Mol Cell Endocrinol 1995;109:151-157.

50 Bruder JM, Drebs WD, Nett TM, Wierman ME: Phorbol ester activation of the protein kinase $\mathrm{C}$ pathway inhibits gonadotropin-releasing hormone gene expression. Endocrinology 1992;131:2552-2558.

51 Wierman ME, Bruder JM, Kepa JK: Regulation of gonadotropin-releasing hormone gene expression in hypothalamic neuronal cells. Cell Mol Neurobiol 1995;15:79-88.

52 Roy D, Belsham DD: Melatonin receptor activation regulates $\mathrm{GnRH}$ gene expression and secretion in GT1-7 GnRH neurons. Signal transduction mechanisms. J Biol Chem 2002;277:251-258. 
53 Bokoch GM: Interplay between Ras-related and heterotrimeric GTP binding proteins: lifestyles of the BIG and little. FASEB J 1996; 10:1290-1295.

-54 Van Biesen T, Hawes BE, Raymond JR, Luttrell LM, Koch WJ, Lefkowitz RJ: $\mathrm{G}_{0}$-protein $\alpha$-subunits activate mitogen-activated protein kinase via a novel protein kinase C-dependent mechanism. J Biol Chem 1996;271: 1266-1269.

55 Rozengurt E: Signal transduction pathways in the mitogenic response to $\mathrm{G}$ protein-coupled neuropeptide receptor agonists. J Cell Physiol 1998;177:507-517.
56 Martinez de la Escalera G, Choi ALH, Weiner RI: Signaling pathways involved in GnRH secretion in GT1 cells. Neuroendocrinology 1995;61:310-317.

57 Moretto M, Lopez FJ, Negro-Vilar A: Endothelin-3 stimulates luteinizing hormone-releasing hormone (LHRH) secretion from LHRH neurons by a prostaglandin-dependent mechanism. Endocrinology 1993;132: 789-794.

58 Vitalis EA, Costantin JL, Tsai PS, Sakakibara H, Paruthiyil S, Iiri T, Martini JF, Taga M, Choi AL, Charles AC, Weiner RI: Role of the cAMP signaling pathway in the regulation of gonadotropin-releasing hormone secretion in GT1 cells. Proc Natl Acad Sci USA 2000; 97:1861-1866.
59 Milasta S, Evans NA, Ormiston L, Wilson S, Lefkowitz RJ, Milligan G: The sustainability of interactions between the orexin-1 receptor and $\beta$-arrestin- 2 is defined by a single $\mathrm{C}$ terminal cluster of hydroxy amino acids and modulates the kinetics of ERK MAPK regulation. Biochem J 2005;387:573-584.

60 Ammoun S, Johansson L, Ekholm ME, Holmqvist T, Danis AS, Korhonen L, Sergeeva OA, Haas HL, Akerman KE, Kukkonen JP: OX1 orexin receptors activate extracellular signal-regulated kinase in Chinese hamster ovary cells via multiple mechanisms: The role of $\mathrm{Ca}^{2+}$ influx in OX1 receptor signaling. Mol Endocrinol 2006;20:8099. 